\title{
Bleak Prospects for Research in GMP in Switzerland
}

\author{
Peter Hettich and Simone Walther*
}

\begin{abstract}
Many European countries, including Switzerland, share deep suspicions about the broad commercial application of Genetically Modified Plants (GMP) in agriculture. Research in GMP, however, is mostly welcome. In Switzerland, nevertheless, an overprotective legal framework against risks of GMP results in regulatory spillovers for research. This article explores how such expanded legal protection in combination with the application of a strong precautionary principle hampers freedom of research in the field of green gene technology. The authors do not seek, on this occasion, to question the general risk assessment of Swiss legislators and their desire for a high level of protection. However, field trials with GMP will cease to take place if the procedural burdens for researchers are not reduced. In particular, it will be vital to establish research zones ("protected sites") if research in GMP is to continue to take place in Switzerland.
\end{abstract}

\section{Introduction}

Swiss Environmental law follows no uniform standard to regulate activities with inherent risks. It sets a large variety of levels of protection and widely differing procedural steps that require to be fulfilled in order to carry out such activities. There are risk related activities, where impairments seem to be socially accepted, proof of safety is hardly required and legal protection is non-existent. This is particularly true for the "regular and large-scale"1 transgression of legal limits for air pollutants (ozone, nitrogen dioxide, PMio particulates $)^{2}$ or the non-thermal effects of cell phone antennas. ${ }^{3}$

* Peter Hettich is Tenure Track Professor for Economic Constitutional Law and Market Regulation as well as Environmental Law at the University of St. Gallen. Simone Walther is Phd Student at the University of St.Gallen. The authors wish to express their gratitude for the valuable input of Prof. Dr. Beat Keller, Dr. ing. agr. ETH Franz Bigler and his team and Dr. iur et dipl. sc. nat. ETH Stefan Kohler.

1 Federal Statistical Office (FSO)/Federal Office for the Environment (FOEN), Umweltstatistik Schweiz in der Tasche 2009, (Neuchâtel: 2009), at pp. 22 et sqq.

2 Swiss Federal Administrative Court Judgment A-2723/2007 of 30 January 2008 at para. 6 (reversed on formal grounds), reconfirmed in Swiss Supreme Court Judment of 3 March 2009, 1C.108/2008 (refusal to consider the case).

3 Swiss Supreme Court Judgment of 30 August 2000, BGE 126 II 399 , at para. 3b: "[When listing these values the ICNIRP merely consid-
With respect to genetic engineering, however, the burden of proof regarding the safety of, e.g., a field trial, lies with the researcher. Approval procedure allows for intervention of all kinds of interest groups and legal remedies are readily available. ${ }^{4}$ In contrast to genetic engineering in the human area ("red gene technology"), genetic engineering in the extra-human field ("green gene technology") has repeatedly been the object of fundamental political and societal controversies. ${ }^{5}$ In Switzerland, a deep suspicion about green gene technology led to a ban (moratorium) on the commercial use of this technology in agriculture, i.e. the cultivation of genetically modified plants in agricultural industries; this ban has been in effect

ered effects which could be repeated and reproduced and posed a risk to human health. One-time or irreproducible findings, particularly epidemiological examinations and individual experiencenes of 'electro-sensitive' persons had been excluded.]"

4 Likewise Christoph Errass, Öffentliches Recht der Gentechnologie im Ausserhumanbereich (Bern: Schulthess 2006), at p. 195; Frank Haldemann, Verantwortung im Gentechnikrecht - Verfassungsrechtliche Betrachtungen zur Freisetzung gentechnisch veränderter Pflanzen, (Basel: Schulthess 2009), at pp.118 et sqq.; Beatrice Wagner Pfeifer, Das Umweltrecht vor den Herausforderungen der Gentechnologie, (Zurich: Schulthess 1997), at pp. 131 et sqq. (with further references); see also Swiss Supreme Court Judgment of 12 March 2003, BGE 129 II 286 at paras. 4.3-4.5.

5 Torbjörn Fagerström, Christina Dixelius, UIf Magnusson and Jens F. Sundström, "Stop worrying; start growing", 13 EMBO reports (2012), pp.493-497, at p. 496. 
since $2005 \cdot{ }^{6}$ However, Swiss law still allows agricultural research in genetic engineering and GMP. One main objective of Swiss genetic engineering law ${ }^{7}$ is to offer research more legal certainty and reliable research conditions. ${ }^{8}$ Nevertheless, field trials in Switzerland are now one of the focal points of the controversy about GMP. Facing huge regulatory obstacles when seeking approval, researchers have carried out field trials in Switzerland only when they were state funded, as escaping to research friendly countries has not been politically feasible when a research project is funded by the state. Procedures designed to encourage participation in the approval procedure and the implementation of legal remedies open a dialogue with opponents, allow them to reconsider their views and may result in improvements in a field trial; dialogues also serve to instil a sense of fairness with affected neighbours. ${ }^{9}$ The same procedure is, however, prone to abuse when interest groups seek participation in order to prevent a field trial from happening altogether. ${ }^{10}$ Instead of generating new arguments, field trials are used as a platform to utter concerns over technology in general, which might suggest moving the focus of deliberation away from individual research projects. ${ }^{11}$ In the past, some field trials have been delayed for years. ${ }^{12}$

The motivation for implementing a comprehensive approval procedure and related legal remedies in Swiss genetic engineering law lies in the legislators' perception that there is a considerable lack of knowledge in this area, particularly regarding the potential unknown risks of this technology. ${ }^{13}$ As expressed in Article 2 Swiss Genetic Engineering Act (GTG), the precautionary principle controls the determination of the level of protection and the assessment of risks. ${ }^{14}$ Yet, as research renders more and more insights in this field and the technology itself becomes more refined, legislative risk assessments need to be revised and the precautionary principle - in its (European) interpretation as a margin of safety - must give ground as a guiding regulatory principle in this field. Today, not only the risks but also the benefits of genetic engineering have become more apparent ${ }^{15}$, permitting an educated societal decision regarding the use of this technology.

The essay at hand follows this line of thought and discusses specific possible legislative actions that will strengthen Switzerland as a place for research without jeopardizing the legislators' desire for a high level of protection. Where appropriate, regulations for field trials in the European Union and in some of its Member States are also taken into account.

\section{Protection from genetic engineering technology}

\section{Risk assessment in the light of the precautionary principle}

Swiss legislation in the area of green gene technology seeks to ensure that humans, animals and the environment do not suffer harm due to the interaction of genetically modified plants with their surround-

6 See Art. 197 No. 7 BV (in effect until 27 November 2010), Art. 37 a GTG (extension of the moratorium until 27 November 2013).

7 [Swiss Federal Law of 21 March 2003 on Gene Technology in the extra-human field] Bundesgesetz vom 21. März 2003 über die Gentechnik im Ausserhumanbereich (Gentechnikgesetz, GTG, SR 814.91).

8 Swiss Federal Council Dispatch of 1 March 2000 [regarding an amendment of the Federal Environmental Protection Law] zu einer Änderung des Bundesgesetzes über den Umweltschutz (USG), in Federal Gazette, BBI 2000 2391, at pp.2393, 2402 and 2427.

9 Melanie Connor, Die Schweizer Bevölkerung und die Grüne Gentechnologie, Presentation at the 5th Symposium on green gene technology of the Zurich-Basel Plant Science Center, held 2 September 2011.

10 Further Niklas Luhmann, Soziologie des Risikos, (Berlin: Gruyter 2003), at pp. 148 et sqq.; cf. Fagerström, Dixelius, Magnusson and Sundström, "Stop worrying; start growing", supra note 5, at p. 496.

11 Rainer Wolf, "Zur Antiquiertheit des Rechts in der Risikogesellschaft", 15 Leviathan (1987), at p. 391; see also Hansjörg Seiler, Recht und technische Risiken:Grundzüge eines technischen Sicherheitsrechts, (Zurich: vdf Hochschulverlag an der ETH 1997), at p. 85.

12 In the case of the field release trial with transgenic KP4 wheat in Lindau/ZH the Swiss Federal Institute of Technology Zurich submitted an application with the FOEN, which was initially refused due to incompleteness. The submission of a revised application took place on 4 January 2001. The FOEN approved the latter application but imposed conditions and additional requirements. As a consequence of several appeal proceedings (i.a. BGE 129 || 286) the approving decision did not become res judicata until 27 February 2004. The sowing of the transgenic KP4 wheat on the trial field in Lindau was finally effected on 18 March 2004.

13 See for example [Statement] Votum Bürgi, Official Bulletin of the Federal Assembly, Council of States' summer session 2001 of 13 June 2001, at pp.302 et sqq.; [Statement] Votum Plattner, Official Bulletin of the Federal Assembly, Council of States' summer session 2001 of 13 June 2001, at pp. 304 et sqq.

14 Swiss Federal Council Dispatch USG, supra note 8, at p. 2431.

15 In the area of green gene technology one must particularly consider the quantitative and qualitative improvement of the crop yield in plants, e.g. by increasing resistance against diseases, vermin, herbicides, extreme temperatures, drought or oligotrophic soil. Furthermore, gene technology opened up the potential for the systematic stimulation of the production of pharmaceutically desired substances or other useful raw materials. See thereto Deutsche Forschungsgemeinschaft (DFG) (ed.), Grüne Gentechnik, (Weinheim: WileyVCH 2010), at pp. 39 et sqq.; Frank Kempken and Renate Kempken, Gentechnik bei Pflanzen - Chancen und Risiken, 3rd ed., (Berlin/ Heidelberg: Springer 2006), at pp. 125 et sqq.; H.S. Chawla, Introduction to Plant Biotechnology, 3rd ed., (Enfield: Science Publishers 2009), at pp. 459 et sqq.; Fagerström, Dixelius, Magnusson and Sundström, "Stop worrying; start growing", supra note 5, at pp. 493 et sqq.; Andrew Apel, "The costly benefits of opposing agricultural biotechnology", 27 New Biotechnology (2010), at pp. 635 et sqq. 
ings. ${ }^{16}$ Invoking the precautionary principle, the use of genetic engineering shall be allowed only "when risks are foreseeable and when a practical, sustainable benefit is possible". 17 When applying genetic engineering in agriculture, "no risk for humans and the environment" shall be tolerated. ${ }^{18}$ The approval process for field trials has to balance the risks of the project with its benefits, in particular the "benefit for the general public". ${ }^{19}$ This benefit for the general public shall consist, at least, of a contribution to biosafety research obtained by the field trial. ${ }^{20}$ The legislators' intention is that such contributions to biosafety re-

16 Swiss Federal Council Dispatch USG, supra note 8, at pp. 2392 et sqq.; Official Bulletin of the Federal Assembly, Council of States' summer session 2001 of 13 June 2001, at p. 302 and Official Bulletin of the Federal Assembly, National Council's autumn session 2002 of 1 October 2002, at p. 1539; see also Rainer J. Schweizer, Kommentar zu Art. 120 BV, in Bernhard Ehrenzeller, Philippe Mastronardi, Rainer Schweizer, Klaus A. Vallender (eds), Die Schweizerische Bundesverfassung, Kommentar, 2nd ed., (Zurich: Dike 2008), Art. 120 BV, at para. 5.

17 Swiss Federal Council Dispatch USG, supra note 8, at p. 2393.

18 Ibid., at p. 2426.

19 Ibid., at p. 2406, 2430.

20 Art. 6 Para. 2 Subpara.b GTG.

21 Swiss Federal Council Dispatch USG, supra note 8, at pp. 2406, 2426 and 2430.

22 Which would in turn have to be addressed as a problem of externalities. Thereto W. Kip Viscusi, Joseph E. Harrington and John M. Vernon, Economics of Regulation and Antitrust, 4th ed., (Cambridge: MIT Press 2005), at pp.746 et sqq.

23 Peter Hettich and Simone Walther, "Schutz (vor) der Gentechnologie", in Franco Lorandi and Daniel Staehelin (eds), Innovatives Recht (Zurich: Dike, 2011), pp.65-86, at p. 71.

24 Udo Di Fabio, Risikoentscheidungen im Rechtsstaat: Zum Wandel der Dogmatik im öffentlichen Recht, insbesondere am Beispiel der Arzneimittelüberwachung, (Tübingen: Mohr Siebeck 1994), at p. 56; Eugene Bardach and Robert A. Kagan, Going by the Book: The Problem of Regulatory Unreasonableness (New Brunswick: Transaction Publishers, 2002), at pp. 196 et sqq.

25 Art. 11 Para. 1 GTG.

26 Ulrich Häfelin, Georg Müller, Felix Uhlmann, Allgemeines Verwaltungsrecht, 6th ed. (Zurich: Schulthess 2010), paras.2523 et sqq., and para. 2534.

27 Art. 19 Para. 1 and 2 in conjunction with Art. 37 para. 1 [Ordinance of 10 September 2008 on the handling of organisms in the environment (Release Ordinance)] Verordnung vom 10. September über den Umgang mit Organismen in der Umwelt (Freisetzungsverordnung, FrSV, SR 814.911). Cf. also Stefan Kohler, Freisetzungen von gentechnisch veränderten Organismen in der Schweiz, (St. Gallen: Vdf Hochschulverlag 2005), at pp. 132 et sqq.

28 Cf. Art. 6 para. 2 Directive 2001/18/EC of the European Parliament and of the Council of 12 March 2001 on the deliberate release into the environment of genetically modified organisms and repealing Council Directive 90/220/EEC.

29 Cf. Art. 6 para. 1 Directive 2001/18/EC of the European Parliament and of the Council of 12 March 2001 on the deliberate release into the environment of genetically modified organisms and repealing Council Directive 90/220/EEC. search will lead to wider public acceptance of the "remaining uncertainties" of gene technology. ${ }^{21}$

The genetic engineering law counteracts possible negative externalities often observed when analysing impairments of the environment, providing a possible economic rationale for intervention by legislators. Accordingly, the direct benefit of products and processes derived from genetic engineering vests almost exclusively in the producing or researching entity, whereas the risk of these products is borne by the general public (including the entity in question). ${ }^{22}$ The interplay of benefits and risks could encourage an entity to underestimate the potential for harm when weighing the advantages and disadvantages of the use of gene technology. As a result, such an entity would apply genetic engineering even where society as such would refrain from such use. ${ }^{23}$ On the other hand, a regulatory agency is subject to the same set of incentives: It bears most of the political fallout in the event of accidents but has no ability to derive any benefits from a new technology. This may act as an incentive to implement sweeping and overcautious regulation. ${ }^{24}$

\section{Preventive control for implementation of the protective duty}

Any release of genetically modified organisms in a field trial in Switzerland must be approved by the competent authority. ${ }^{25}$ The applicant has a legally enforceable right for the permit to be granted provided all statutory prerequisites are met. ${ }^{26}$ The competent authority, the Swiss Federal Office for the Environment (FOEN), grants the permit if the request, which includes a risk assessment, shows that humans and the environment will not be harmed. In order to be approved, the request further needs favourable assessments from the Federal Office of Public Health (FOPH), the Federal Veterinary Office (FVO), the Federal Office for Agriculture (FOAG), the Federal Expert Committee for Biosafety (FECB), the Federal Ethics Committee on Non-human Biotechnology (ECNH), and the designated authority of the canton in question. ${ }^{27}$

Similar rules apply for the authorisation of experimental field trials within the European Union. Art. 6 Directive 2001/18/EC requires applicants (called notifiers) to submit a technical dossier including an environmental risk assessment carried out by the notifier. ${ }^{28}$ Since the application has to be filed with the competent authority named by the respective Member State ${ }^{29}$, approval practices (e.g. the scien- 
tific evaluation or the risk management measures imposed) differ due to the variations in the national and regional regulations which implement the above mentioned Directive. The power to approve or reject the application rests solely with the national authority, which in certain Member States depends on further input from regional authorities, technical advisory bodies or even other member states. ${ }^{30}$

In Switzerland, to date, seven applications for field release trials have been filed with the FOEN, five thereof have been approved. Likewise, only a few permits have been issued for putting genetically modified organisms into circulation as animal feed or foodstuffs. ${ }^{31}$ With regard to the commercial use of genetically modified plants, seeds and animals in agriculture, authorities have been completely barred from granting permits due to a legal moratorium lasting until 27 November $2013 .{ }^{32}$ The moratorium's purpose is to wait for further scientific results regarding biosafety, in particular the results of the National Research Program 59 on "Benefits and Risks of the Field Release of Genetically Modified Plants". ${ }^{33}$

Requests for field trials are published in the Federal Gazette. The non-confidential files are open to inspection by the public. ${ }^{34}$ Anyone may comment on the files in written form, regardless of his or her legal standing. ${ }^{35}$ Thus, the approval process is supplemented with extensive public participation rights. Participation of locals may help in determining the relevant factual circumstances, with the added benefit that it might help to compensate for the lack of reliable scientific knowledge - as is typical in risk areas - and might constitute a procedural counterweight for vague substantive standards of approval. ${ }^{36}$ Even if participation does not generate new arguments ${ }^{37}$, the transparency of the procedure and the quality of the authorities' reasoning is improved. Responding to objections raised, however, is associated with considerable expense for the researchers and is not possible without legal counsel.

When approving field trials, the FOEN and the courts have rarely denied a person legal standing or rights to appeal. When deciding on a field trial, the Swiss Supreme Court held that the right to appeal in risk areas must not be construed narrowly. ${ }^{38}$ In a field trial concerning wheat, rye or wheat-rye hybrids, the FOEN has granted legal standing to neighbours who are within the range of airborne pollen of the genetically modified plants. For the maximum airborne pollen range, the FOEN has relied on studies of researchers who were able to find viable pollen at a distance of 1,000 $\mathrm{m}$ from a very large pollen source. ${ }^{39}$ In contrast, the expert opinion of the Swiss Expert Committee for Biosafety (SECB) focuses on the avoidance of hybridization, which is the relevant factor from a biological and agronomical viewpoint; applying this focus to the question of legal standing, a limit of $300 \mathrm{~m}$ between the trial fields and the nearest area used agriculturally for cultivation of wheat, rye or wheat-rye hybrids would be adequate. ${ }^{40}$ To this day, the courts have not decided on the question of the extent of the perimeter granting legal standing. ${ }^{41}$

30 Sonia Gómez-Galera, Richard M. Twyman, Penelope A.C. Sparrow et al., "Field trials and tribulations - making sense of the regulations for experimental field trials of transgenic crops in Europe", Plant Biotechnology Journal (2012), at pp.1-13, DOI 10.1111/j.1467-7652.2012.00681.x, at pp. 2 et sqq.

31 FOAG, "Gesuche und Bewilligungen für GVO-Erzeugnisse", 20 December 2010, available on the Internet at <www.bag.admin. ch/themen/lebensmittel/04858/04863/04883/index.html?lang=de> (last accessed on 12 July 2012); [Appendices of the Ordinance of the FOAG of 1 February 2005 on GMO animal feed lists] Anhänge der Verordnung des Bundesamtes für Landwirtschaft (BLW) vom 1. Februar 2005 über die GVO-Futtermittellisten (SR 916.307.11).

32 Art. 37a GTG.

33 Swiss Federal Council Dispatch of 1 June 2009 [regarding the amendment of the Swiss Federal Law on Gene Technology in the extra-human field] zur Änderung des Gentechnikgesetzes (GTG), in Federal Gazette, BBI 2009 5435, at pp. 5436 and 5441.

34 Art. 36 para. 2 FrSV.

35 Art. 36 para. 3 FrSV.

36 Errass, Öffentliches Recht der Gentechnologie im Ausserhumanbereich, supra note 4, at p. 195. See also Swiss Supreme Court Judgment of 12 March 2003, BGE 129 II 286, para.4.3.3.

37 Seiler, Recht und technische Risiken, supra note 11, at p.85; Wolf, "Zur Antiquiertheit des Rechts in der Risikogesellschaft", supra note 11, at p. 391.

38 Cf. Swiss Supreme Court Judgment of 12 March 2003, BGE 129 II 289, para.4.3.2

39 FOEN, decision on granting a permit regarding the field release trial B07001 of 3 September 2007, Section B.2.2.1.2, Para. 4, available on the Internet at <www.bafu.admin.ch/biotechnologie/01756/08902/08924/index.html?lang=de > (last accessed on 12 July 2012).

40 SECB, opinion to the field release trial B07001 of 20 July 2007, no. 4.3. It seems noteworthy here, that minimum distances to avoid hybridization are also to be adhered to with regard to the preservation of sorting accuracy in conventional plant breeding, e.g. in wheat. However, as regards oat, spelt, barley and soft wheat it is sufficient to clearly separate neighboring fields of different sorts, e.g. by one plough share (approx. $3 \mathrm{ft}$. gap). Thereto appendix 3 no. 2.3 [Ordinance of 7 December 1998 on seeds of field and forage crops as well as vegetable varities] Verordnung des EVD vom 7. Dezember 1998 über Saat- und Pflanzengut von Acker- und Futterpflanzen- sowie Gemüsearten (Saat- und Pflanzengut-Verordnung des EVD, SR 916.151.1).

41 Swiss Supreme Administrative Court Judgment of 10 November 2008, A-6728/2007, para. 3.4. 
By focusing on the airborne pollen range, legal standing and the right to appeal concerning field trials depend on the respective trial plants. For potatoes, which proliferate mainly by tuber cloning, the legitimization perimeter could be set at $20 \mathrm{~m}$. For rape, the pollen of which is dispersed by wind and insects, a considerably larger perimeter would be necessary. In the case of corn, 95 to $99 \%$ of the pollen falls to the ground in a radius of $30 \mathrm{~m}$ around the pollen source. ${ }^{42}$ The number of pollen grains of all these plants decreases exponentially with increasing distance, but drops to approximately zero

42 DFG, Grüne Gentechnik, supra note 15, at pp. 85 et sqq.

43 That is, just those inhabitants who were immediately and evidently more severely threatened by the effects of a nuclear power plant than the general public - in normal operation state as well as in the eventof accident - were entitled to appeal. Cf. Federal Council, Decision No. 96 in VPB 42 of 22 February 1978, para. 4; See also Decision No. 89 in VPB 44 of 14 May 1980, para. 3; Decision No. 54 in VPB 46 of 29 April 1982, para. 2; Swiss Supreme Court Judgments of 19 May 1995 BGE 121 II 176, para. 2c and 18 November 1994, BGE 120 IB 379, para. 4d.

44 Cf. Federal Council, Decision No. 96 in VPB 42 of 22 February 1978, para. 4

45 Hettich and Walther, "Schutz vor der Gentechnologie", supra note 23 , at p. 77 . This question, which implicitly challenges the suitability of solely considering the airborne pollen range, has also been raised by the Swiss Supreme Administrative Court. See Judgment of 10 November 2008, supra note 41, para.3.4.

46 The latter consideration has been brought up by the European Court of Justice (ECJ) in a recent judgment on pollen of genetically modified corn (MON810) in honey. Cf. Case C-442/09, paras. 100 et sqq. According to Errass, the same would apply for Swiss Law. Cf. Christoph Errass, "Honig mit gentechnisch veränderten Pollen: Ein Urteil des EuGH und die Folgen für die Schweiz", Jusletter 17 October 2011, para.10. See also Art. 12 para. 1 GTG; Art. 22 para. 1 e contrario [Ordinance of 23 November 2005 on foodstuffs and commodities] Lebensmittel- und Gebrauchsgegenständeverordnung vom 23. November 2005 (LGV; SR 817.02); Art. 19 [Ordinance of 26 October 2011 on the production and putting into circulation of animal feed] Verordnung vom 26. Oktober 2011 über die Produktion und das Inverkehrbringen von Futtermitteln (Futtermittel-Verordnung, FMV, SR 916.307).

47 See Art. 6a and 7 [Ordinance of the Federal Department of the Interior on genetically modified foodstuffs of 23 November 2005] Verordnung des EDI über gentechnisch veränderte Lebensmittel vom 23. November 2005 (VGVL, SR 817.022.51). The above mentioned threshold value for traces of unauthorized GMO in organic products $(0.5 \%$ per ingredient) is not to be confused with the higher threshold value $(0.9 \%$ per ingredient) for mixing authorized GMO with conventional organisms within the flow of goods (e.g. mixing seeds, grains, etc.).

48 Cf., e.g., Swiss Supreme Court Judgment of 10 September 1997, BGE 123 II 376, paras. 2 and 4a (Ideological nuisance through the authorisation of GM-soy as a food product); Judgment of 28 March 1995, 1A.98/1994, para. 2c (line-of-sight obstruction through planting); Judgment of 31 January 2008, 1C.262/2007, paras. 1.2 and 2.4 et sqq. (running a soup kitchen); see also Hettich and Walther, "Schutz (vor) der Gentechnologie", supra note 23, at p. 78. With further references to ideological nuisance in the law concerning the respective interests of neighbours Arthur Meier-Hayoz (ed.), Kommentar zum Schweizerischen Privatrecht, Vol. 4, Art. 648 ZGB at paras. 72 et sqq. only at great distances. The use of the airborne pollen range for determining the legal standing and the right to appeal implies that the mere possibility of a single pollen being carried into a garden constitutes a substantive gravamen. ${ }^{43}$ The population within an area of up to $3 \mathrm{~km}^{2}$ would be entitled to file appeals against approvals of field trials. In Switzerland, such an area covers whole municipalities. As a result, it is theoretically possible to file some kind of class action against field trials, which is otherwise unknown in Switzerland. For the sake of comparison, perimeters of similar extent have been applied in the context of approval procedures for nuclear power plants (zones of $4-5 \mathrm{~km}$ around a nuclear power plant). ${ }^{44}$ These authors firmly believe, being humble lawyers, that the risks associated with nuclear power plants are not comparable with those of a small-area field trial.

It seems obvious that the law needs to provide answers on whether and when the potential entry of pollen onto a plot of land provides legal standing and a right to appeal. For legal standing to be granted to a person, it seems reasonable to distinguish whether this person uses a plot of land for residential or for agricultural purposes. If the appellant engages in agricultural activities and cultivates plants that could well hybridise (i.e. cross-pollinate) with the genetically modified plants, legal standing should be granted. ${ }^{45}$ In the case of relatively heavy unintended pollen input (so called adventitious presence), such an appellant could be exposed to the risk that its plants would feature unauthorized genetically modified contents, resulting in the entire harvest being barred from sale as food or animal feed due to lack of governmental approval and the absence of proof of harmlessness to human health. ${ }^{46}$ Even in cases where an official authorization of the genetically modified contents can be effected ex post, the harvest would have to be labelled "genetically modified" when exceeding the applicable threshold value. ${ }^{47}$ In current market conditions, such a label would result in economic loss. However, even if a plot of land is used for agricultural use, the distance prone to hybridization is usually much shorter than the airborne pollen range. If, in contrast, the appellant uses a plot of land for residential, commercial or industrial purposes, the potential impairment by pollen of a genetically modified plant appears to be a purely ideological nuisance. Such ideological nuisance may provide a right to appeal only in a very limited way - at best in the immediate neighbourhood of a trial field. ${ }^{48}$ 


\section{Protection of genetic engineering technology}

\section{Risk assessment in the light of the current research status}

The legal systems of continental Europe appear to have great difficulty with the timely inclusion of empirically obtained data, especially from the natural sciences, in their deliberations and findings. The time lag between the finding of new data and its integration into legal doctrine, court decisions, and the law is worryingly large, considering the speed of innovative change in areas like biotechnology. For at least twenty years, court decisions have regularly referred to the special obligation of the legislators to exercise caution in the area of genetic engineering due to the perceived unclarified knowledge of science, especially in the evaluation of causal relationships and long-term consequences. ${ }^{49}$ In its judgement of 24 November 2010, the German Constitutional Court did not even bother to include references to the (natural) scientific discussion. The Court held instead that “the assumption of a 'basic risk' [...] lies within the appraisal prerogative of the legislator and that such assumption does not require any scientific or empirical proof of a hazard potential of genetically modified organisms and their offspring." The Court reasoned that precaution is justified because science has not yet rendered clear results on the risks involved. Without such clear results, legislators have a lot of leeway to assess the hazard situation and risks, considering that human health and the environment enjoy a high level of protection under constitutional law. ${ }^{50}$ Consequently, courts pay a lot of deference to protective measures implemented in risk areas, often refraining from a full review of decisions rendered by administrative bodies and interfering only if the protective measure is arbitrary and capricious. ${ }^{51}$

On the basis of our work with practitioners in the field, mainly working with Universities and with publicly funded research centres, we came to believe that lawmakers and courts can no longer base their decisions on a "scientifically unclarified situation" in the area of genetic engineering. This conclusion is supported by the European Commission, which, on 9 December 2010, published a comprehensive presentation of a decade of EU-supported research on genetically modified organisms. ${ }^{52}$ The report describes a total of 50 research projects, which mainly explored the safety of genetically modified organisms for the environment and the health of humans and animals. These projects were initiated between 2001 and 2010 and were funded by the EU with EUR 200 million. Since 1982, research in this area has received over EUR 300 million of EU funding. ${ }^{53}$ The project results revealed no scientific evidence to suggest that genetically modified organisms represent a greater danger for the environment or for foodstuff and animal feed safety than conventional organisms do. ${ }^{54}$

Internationally, genetically modified crops have been cultivated over large areas for 15 years. In 2010, the cultivation area for genetically modified plant species increased to 148 million hectares in total which corresponds to around $10 \%$ of the worldwide arable area, as reported by the Food and Agriculture Organization (FAO) of the United Nations. ${ }^{55}$

When approving one of the first field trials on 30 October 2003, the FOEN ordered researchers to implement additional safety measures, amounting to three pages of the permit. Considering the state of scientific knowledge today, these safety measures

49 E.g. German Federal Constitutional Court Judgment of 24 November 2010, BVerfG, 1 BvF 2/05, para. 137.

50 German Federal Constitutional Court Judgment of 24 November 2010, BVerfG, 1 BvF 2/05, para.142. However, cf. Case C-236/01, Monsanto Agricoltura Italia SpA v. Presidenza del Consiglio dei Ministri [2003], at paras. 106 et sqq., where the European Court of Justice (ECJ) held, that "protective measures adopted under the safeguard clause may not properly be based on a purely hypothetical approach to risk, founded on mere suppositions which are not yet scientifically verified ", but require a "risk assessment $[\ldots]$ as complete as possible".

51 Peter Hettich, "Pharmarecht als Risikorecht", in Peter Hettich and Stefan Kohler (eds.), St. Galler Tagung zum Pharmarecht, (St. Gallen: Schulthess 2010), at pp. 15 et sqq.

52 European Commission, EUR 24473 - A Decade of EU-funded GMO reserach (2001-2010), (Luxembourg: Publications Office of the European Union 2010).

53 European Commission, A Decade of EU-funded GMO reserach (2001-2010), supra note 52, at p. 15

54 European Commission, "Commission publishes compendium of results of EU-funded research on genetically modified crops", Press release of 9 December 2010, available on the Internet at <europa. eu/rapid/pressReleasesAction.do? reference $=I P / 10 / 1688 \&$ format $=H$ TML\&aged=0\&langulan=DE $>$ (last accessed on 12 July 2012); European Commission, supra note 52, at pp. 16 et sqq.; DFG, supra note 15, at p. 91; cf. also Economist Online, "Green Genes - The shameful destruction of a crop trial", 4 August 2008, available on the Internet at <www.economist.com/node/11871937> (last accessed 12 July 2012). See also Gómez-Galera, Twyman, Sparrow et al., "Field trials and tribulations", supra note 30, at p. 11; Fagerström, Dixelius, Magnusson and Sundström, "Stop worrying; start growing", supra note 5, at p. 496.

55 Clive James, "Global Status of Commercialized Biotech/GM Crops: 2010", International Service for the Acquisition of Agri-Biotech Applications (ISAAA), Brief No. 42, 22 February 2011, available on the Internet at $<w w w$.isaaa.org/resources/publications/briefs/42/ executivesummary/default.asp > (last accessed on 12 July 2012). 
seem anachronistic. ${ }^{56}$ At that time, the applicant, bearing costs of the application amounting to 13,800 Swiss francs, was ordered to take the following actions, including the:

56 FOEN, "Decision on permit B00003", 30 October 2003, available on the Internet at <www.bafu.admin.ch/biotechnologie/01756/08902/08928/index.html?lang=de > (last accessed on 12 July 2012).

57 Cass R. Sunstein, "Probability Neglect: Emotions, Worst Cases, and Law", 112 Yale Law Journal (2002), at p. 104 (also arguing as an analogue that mandatory labels of genetically modified food might be criticized on the ground that they suggest a danger that does not in fact exist). Cf. also Timur Kuran and Cass R. Sunstein, "Availability Cascades and Risk Regulation", 51 Stanford Law Review (1999), at p. 707 , arguing that if alarmist information is more salient, and thus more readily recalled, the public may end up exaggerating the gravity of certain risks (availability cascade).

58 FOEN, "Decisions on permits B07001 and B07002", 3 September 2007, available on the Internet at $<w w w . b a f u . a d m i n . c h / b i o t e c h-$ nologie/01756/08902/08924/index.html?lang=de $>$ (last accessed on 12 July 2012). Unlike in its decision on permit B00003 of 30 October 2003, the FOEN in 2007 abstained for example from imposing pollen tents, fly screens or framing with sheet metal.

59 The article at hand assesses risk from a strictly natural scientific angle in order to allow for rational, science-based decision-making. Therefore, other factors, e.g. ethical or philosophical questions are not being considered in the risk assessment. For a general discussion on the relationship between expert opinion and popula concerns see Cass R. Sunstein, Risk and Reason, Safety, Law and the Environment, (Cambridge: Cambridge University Press 2002), at pp. 53 et sqq. See also Galera, Twyman, Sparrow et al., "Field trials and tribulations", supra note 30 , at p. 11 .

60 Consenting Kempken and Kempken, Gentechnik bei Pflanzen, supra note 15, at pp. 185 et sqq.; Chawla, Introduction to Plant Biotechnology, supra note 15, at pp. 521 et sqq.; DFG, Grüne Gentechnik, supra note 15 , at p. 92.

61 Though possible measures to practically implement co-existence are being examined in scientific studies (cf. e.g. Antoine Messéan, F. Angevin, M. Gomez-Barbero et al., New case studies on the coexistence of GM and non-GM crops in European agriculture, European Commission (ed.), (Sevilla: Publications Office of the European Union 2006); Kathrin Pascher, Marion Dolezel, Koexistenz von gentechnisch veränderten, konventionellen und biologisch angebauten Kulturpflanzen in der Österreichischen Landwirtschaft Handlungsempfehlungen aus ökologischer Sicht, Federal Ministry of Health (ed.), (Vienna 2005)) all proposals to prevent undesired hybridisation - besides separating or cleaning harvesters and choosing cultivars with different points of anthesis - result in the adherence to certain field separation distances (depending on the plant species up to several kilometers), including possibly extensive monitoring. This leads to vigorous discussions even in countries much larger by surface area than Switzerland, such as the U.S. Thereto Economist Online, "Rows over GM crops - Seeds of Change", 6 January 2011, available on the Internet at <www.economist.com/ node/17855118 > (last accessed on 12 July 2012). In the European Union, the recent $\mathrm{ECJ}$ ruling regarding pollen of genetically modified corn (MON810) in honey raises major questions concerning the implementation of co-existence. Cf. Case C-442/09, paras. 100 et sqq. For an overview on the coexistence policy in the European Union see Justo Corti Varela, "The New Strategy on Coexistence in the 2010 European Commission Recommendation", 4 EJRR (2010), pp. 353 et sqq. In Switzerland the following authors dealt with the co-existence issue: Manuela Dahinden, Stefan Kohler, Christof Sautter, Koexistenz und Froschungsfreiheit als Nagelprobe für die Grüne Gentechnologie, (Zurich: Idea 2011); Astrid Epiney, Bernhard Waldmann, Magnus Oeschger, Jennifer Heuck, Die Ausscheidung von gentechnikfreien Gebieten in der Schweiz de lege lata et de ferenda, (Zurich/St. Gallen: Dike 2011); Errass, "Honig mit gentechnisch veränderten Pollen", supra note 46, at paras. 7 et sqq.
- Appointment of a chaperon group at its own costs;

- Registration of all cultivated areas within a radius of $500 \mathrm{~m}$;

- Coverage of the trial area with bird nets, framing with sheet metal to keep out rodents and insect screens to prevent germ buds from being washed away;

- Coverage of the wheat plants with pollen-proof fabrics (pollen tents) during the flowering period;

- Regular soil samples within and samples of the coated seed;

- Cleaning, if possible by autoclaving, of all working implements;

- Removal of all plant material to a refuse incinerator, heat treatment of the soil and of the protective coated seed.

- Observation of the trial fields for one to two years;

If these safety measures were intended to instil a feeling of safety into the population, they probably failed. On the contrary, the safety measures presumably reinforced biases and caused anxiety. The availability heuristic suggests that "if government attempts to reduce fear by regulating the activity that produces it, it might well intensify that very fear, simply by suggesting that the activity is worth regulating." ${ }^{17}$ The safety measures forced the field trial into a half-closed system, putting into question the purpose of the release trial itself. Furthermore, safety measures such as those which cover the genetically modified plants with pollen tents limit the potential to gain knowledge about biosafety, since surveys of insects, for example, cannot be conducted under these conditions. At least, the FOEN requested somewhat more modest safety measures when approving field trials with genetically modified wheat strains on 3 September $2007 .{ }^{58}$

It is not the intention of the authors to give the impression that trials with genetically modified plants are without risk. ${ }^{59}$ Nevertheless, the risks involved with field trials on genetically modified organisms appear to be well known today, limited in probability of occurrence and extent of harm, as well as controllable by reasonable preventive safety measures. ${ }^{60}$ Whether research on genetically modified plants should take place in Switzerland is a question of political will rather than a question of biosafety. Nevertheless, whether and how the coexistence between conventional production and production with genetically modified plants will be possible in the long term, as required in Article 7 GTG, still seems unclear. ${ }^{61}$ The decision on commercial use of these 
plants is, however, separate from the decision on research.

To abandon research and commercial use of gene technology bears risks of its own, which lawmakers and courts should consider in any decision about the use of this technology. These risks do not always have to be as dramatic as in the case of Zambia, where the government, despite famine, declined emergency supplies of genetically engineered corn, on the grounds of the precautionary principle and the lack of evidence of safety. ${ }^{62}$ The European Commission estimates that the world population will increase to 9 billion people by $2050 .{ }^{63}$ Furthermore, mankind will probably not be able to limit the temperature rise to the $2^{\circ}$ Celsius necessary to moderate the effects of climatic change. ${ }^{64}$ Extinction of species, droughts, floods and storms will be consequences of this climatic change. ${ }^{65}$ Genetically modified plants have the potential, especially in less developed countries, to prevent under-nutrition, to increase harvest yields and to contribute to the adaptation of agriculture to climate change. ${ }^{66}$ Even in developed countries, genetically modified plants may contribute to increase self-supply in agricultural production (net value of $56.0 \%$ in Switzerland in $2009^{67}$ ) and may render agricultural production more ecological - assuming that genetically modified plants reduce the demand for fertilizers and plant protection agents. ${ }^{68}$

\section{Promotion of research as a constitutional duty}

The research activities of private research institutions and researchers are protected by scientific freedom (Article 20 Constitution) and economic freedom (Article 27 Constitution). These constitutional rights are subject to standard restrictions according to Article 36 Constitution (three tier test: legal basis, public interest, proportionality). ${ }^{69}$ In risk areas, courts routinely deem restrictions to be both in the public interest and proportionate, when they are established to protect life, health, and the environment. ${ }^{70}$ Due to this deference, it is left to legislators to determine the relationship between scientific freedom and social responsibilities. $^{71}$

Whether the State has a general obligation to promote innovation alongside and with private research still requires clarification; sometimes an obligation to disseminate desired innovation services has been derived from the so called social state principle. ${ }^{72}$ In Switzerland, the government promotes scientific research and innovation on the basis of Article 64 of the Constitution. By the term "innovation", the Commission for Science, Education and Culture of the National Council (WBK-N) means the development of innovative products and services for society and the economy, and therefore specifically the knowledge transfer from research into industry. ${ }^{73}$ However, the term innovation may

62 Cass R. Sunstein, Laws of Fear - Beyond the Precautionary Principle, (Cambridge: Cambridge University Press 2005), at pp. 31 et sqq. (citing studies of WHO, which estimated 35'000 famine victims due to the refusal); John Bohannon, "Zambia Rejects GM Corn on Scientists' Advice", 298 Science (2002), pp. 1153 et sqq.; Wallace E. Huffman, "Consumers' Acceptance of (And Resistance to) Genetically Modified Foods in High-Income Countries: Effects of Labels and Information in an Uncertain Environment", 85 American Journal of Agricultural Economics (2003), at. p. 1113.

63 European Commission, A Decade of EU-funded GMO reserach (2001-2010), supra note 52, at p. 9.

64 Economist Online, "How to live with climate change -It won't be stopped, but its effects can be made less bad", 25 November 2010, available on the Internet at <www.economist.com/ node/17575027> (last accessed on 12 July 2012).

65 Cf. Martin Parry, Osvaldo Canziani, Jean Palutikof, Paul van der Linden and Clair Hanson, "Impacts, Adaptation and Vulnerability", in IPCC/WMO/UNEP (eds.), Fourth Assessment Report: Climate Change 2007 (Cambridge: Cambridge University Press 2007).

66 European Commission, A Decade of EU-funded GMO reserach (2001-2010), supra note 52, at pp. 7 et sqq.; DFG, Grüne Gentechnik, supra note 15, at pp. 38 et sqq.; Robert Paarlberg, "The Global Food Fight", 79 Foreign Affairs (2000), at pp. 30 et sqq.; Jonas Roos, Richard Hopkins, Anders Kvarnheden and Christina Dixelius, "The Impact of global warming on plant diseases and insect vectors in Sweden", 129 Eur J Plant Pathol (2011), at pp. 9 et sqq.; Rajeev K. Varshney, Kailash C. Bansal, Pramod K. Agarwal et al., "Agricultural biotechnology for crop improvement in a variable climate: hope or hype?", 16 Trends in Plant Science (2011), at. pp 363 et sqq.

67 Federal Department of Economic Affairs (FDEA)/FOAG, Government report on Agriculture 2011, (Bern: 2011), at p. 14.

68 European Commission, A Decade of EU-funded GMO reserach (2001-2010), supra note 52, at pp. 7 et sqq.; European Commission, Press release of 9 December 2010, supra note 54.

69 Gerhard Schmid and Markus Schott, "Kommentar zu Art. 64 BV", in Ehrenzeller, Mastronardi, Rainer and. Vallender (eds), Die Schweizerische Bundesverfassung, supra note 16, Art. 64 BV at para. 4, with reference to Verena Schwander, Grundrecht der Wissenschaftsfreiheit: im Spannungsfeld rechtlicher und gesellschaftlicher Entwicklungen, (Bern: Haupt 2002).

70 Similarly German Federal Constitutional Court in its Judgment of 24 November 2010, BVerfG, 1 BvF 2/05, at paras. 148 et sqq.

71 Dietrich Murswiek, Die staatliche Verantwortung für die Risiken der Technik, (Berlin: Duncker \& Humblot 1985), at p. 23; Hettich and Walther, "Schutz (vor) der Gentechnologie", supra note 23, at p. 82.

72 Ulrich K. Preuss, "Risikovorsorge als Staatsaufgabe", in Dieter Grimm (ed.), Staatsaufgaben, (Baden-Baden: Suhrkamp 1994), pp. 523-551, at p. 543.

73 Schmid and Schott, "Kommentar zu Art. 64 BV", supra note 69, Art. 64 BV at para. 5; WBK-N, Report of 23 June 2005 regarding the parlamentary initiative of a [Constitutional framework Article concerning Education]"Bildungsrahmenartikel in der Bundesverfassung", in Federal Gazette, BBI 2005 5479, at p. 5512. 
also have an interpretation far beyond the context of this constitutional definition. ${ }^{74}$

With regard to genetic engineering, Article 26 Paragraph 1 of the Swiss Genetic Engineering Act (GTG) mentions that the government may commission or support research projects. Also, the information derived from the legislative process indicates that research in the area of gene technology is welcomed and that expansion of the necessary specialist expertise by means of original research is deemed important. ${ }^{75}$ In this light, the approval processes based on this law should not be so construed as to effectively prevent research from taking place.

\section{Need for procedural relief}

The procedure to approve a field trial is mainly defined by the executive branch of the Swiss Government (i.e. the Federal Council, Article 11 Paragraph 2 GTG, FrSV [Release Ordinance]). The approval process needs to ensure that it maintains the high level of protection required by the legislation. If the field trial jeopardizes human health or the environment the field trial will be barred. ${ }^{76}$

74 To the definition see e.g. Christoph Errass, "Innovationsfördernde Regulierung als Aufgabe des öffentlichen Rechts?", 111 ZBI (2010), pp. 203-235, at pp.206 et sqq.

75 Swiss Federal Council Dispatch USG, supra note 8, at pp. 2402 and 2427; Official Bulletin of the Federal Assembly, National Council's spring session 2003 of 5 March 2003, at pp.92 et sqq.; Official Bulletin of the Federal Assembly, Council of States' spring session 2003 of 13 March 2003, at p. 192. Cf. as well Kohler, Freisetzungen von gentechnisch veränderten Organismen in der Schweiz, supra note 27 , at pp. 105 et sqq.

76 Hansjörg Seiler, "Kommentar zu Art. 29e USG", in Helen Keller - Vereinigung für Umweltrecht (eds), Kommentar zum Umweltschutzgesetz, 2nd ed., (Zurich: Schulthess 2003), Art. 29e USG at para. 30.

77 Cf. e.g. Sections C.1.c/dd and C.1.d/uu of the decision on permit B07001 by the FOEN of 3 September 2007 and the related decisions of 6 February 2008 and 6 February 2009 respectively.

78 Cf. also 7 CFR 340.3 (U.S.), which, instead of the usual permit system, allows for a notification procedure when fulfilling certain conditions. The notification per se consists of a two-sided form (an example and the prerequisites to participate in the notification procedure are available on the Internet at $<w w w$.aphis.usda.gov/ biotechnology/downloads/notification_guidance_0810.pdf > (last accessed on 12 July 2012)); see also Hettich and Walther, "Schutz (vor) der Gentechnologie", supra note 23, at pp. 84 et sqq.

79 Swiss Supreme Court Judgment of 10 August 2009, BGE 135 II 338, at paras. 5 et sqq.

80 See Gómez-Galera, Twyman, Sparrow et al., "Field trials and tribulations", supra note 30, at pp.10 et sqq.; European Union Joint Research Centre, List of summary notifications (SNIFs) circulated under Art. 9 of Directive 90/220/EEC and Art. 11 of Directive 2001/18/EC, available on the Internet at <http://mbg.jrc.ec.europa. eu/deliberate/doc/snifs.pdf > and <http://gmoinfo.jrc.ec.europa.eu/> (last accessed on 12 July 2012).
Based on the regulation of the Swiss Government regarding field release, the FOEN requires every single field trial to be approved individually (system of individual permits). Such approvals require to be renewed each year, which affects trials lasting several years. ${ }^{77}$ The Government has been granted the power to simplify the approval procedure or implement an exception from the approval procedure (Article 14 GTG), provided that existing scientific knowledge or experience shows that the required level of protection will still be maintained. The Government has made very limited use of this option, mainly if parts of a field trial have been reviewed in previous approval processes (Articles 18 and 22 FrSV [Release Ordinance]).

De facto, only a few sites in Switzerland are suitable to carry out field trials. These sites are operated by institutions that are already active in agricultural research, such as the "Agroscope Federal Research Institutions". Taking into account the wide discretion granted by Article 11 and 14 GTG, a general framework approval could be granted to these sites. Such a framework or site approval would need to encompass safety measures and further conditions for certain plant species and certain series of trials. If the conditions described by the site approval are fulfilled, field trials could then be carried out after mere notification to the authorities. Because the framework approval just alters procedure, but does not touch the law's substantive standards, it still safeguards the high level of protection required by the legislation and serves to safeguard the interests of neighbours by giving them a single opportunity to ask for a review of the approval by a court. All of this would still result in research on the site being facilitated because field trials could be carried out after notification to the authorities, which preserves the control capabilities of the competent authorities. ${ }^{78}$ In other contexts, the Swiss Supreme Court has upheld such framework approvals, even without explicit statutory grounds. ${ }^{79}$ The Court held that the activities subject to the framework approval must be sufficiently defined as a category and that the competent authorities retain effective options for intervention. To define future research generically in advance is, however, a complex task.

In the European debate on experimental field trials, the argument of simplifying and streamlining application procedures has been brought up as the number of field trial applications has dropped significantly in most EU Member States in recent years (Spain being the main exception). ${ }^{80}$ Surpris- 
ingly, Germany - generally known for a rather slow and unpredictable authorisation procedure for field trials ${ }^{81}$ - also disposes of a simplified procedure ${ }^{82}$, under which the approval of repeated and familiar field releases within the same research project can be sought through a single application procedure. ${ }^{83}$ Furthermore, it allows for repeat notifications which can be processed for different locations. ${ }^{84}$

\section{Need to establish "Protected Sites"}

There are proposals to concentrate risks accompanying certain high-tech activities in so-called risk zones in order to protect the public. ${ }^{85}$ Sometimes, however, risk related activities themselves need protection from certain sectors of the public. On Friday, 13 June 2008 (sic!), approximately 35 activists attacked a trial field cultivated with genetically modified plants in Zurich-Reckenholz and destroyed parts of the field. ${ }^{86}$ During the night of 22 June 2009, unknown persons threw canisters of liquid containing diesel fuel and herbicides on a trial field of genetically modified wheat in Pully, causing damage to soil and crops. ${ }^{87}$ It also seems entirely commonplace elsewhere in Europe for trial fields to be destroyed by activists, with biologists urging them not to do so by distributing video pleas to the mass media. ${ }^{88}$ Such activists rarely face prosecution. Field trials nurtured for several years are jeopardized by such actions and the work of usually numerous researchers is destroyed. Extensive safety precautions and emergency plans are needed for the protection of the research activity.

The research facility of Agroscope in Zurich-Reckenholz is now protected by a $2 \mathrm{~m}$ high double fence of barbed wire and a massive iron gate, which will certainly not stop the activists but may delay them until the police arrive. Video cameras enable constant surveillance of the field. Private security services patrol the property around the clock, generally accompanied by dogs. The costs incurred by these security precautions amount to an initial one-off investment of approximately 400,000 Swiss francs, with annual operating costs of a further 450,000 to even 750,000 Swiss francs (for cultivation of several plant species). The most recent calculations in connection with the field trials of genetically modified wheat within the scope of the National Research Program 59 show that, for each monetary unit (1 Euro) spent for research per se, an additional 78 cents is needed for security precautions, 31 cents for compliance with the biosafety regulations and 17 cents for support and control of the trials by the authorities. ${ }^{89}$ Thus the security costs account for a large part of the entire budget. It is evident that the universities' fundamental research in the field of genetic engineering, supported by the government and also undertaken in the public interest, can no longer be continued if the state does not bear the costs of these security precautions or does not at least create strong legal instruments for passing the costs of these safety precautions onto activists or organizations which publically call for sabotage of

81 See Gómez-Galera, Twyman,. Sparrow et al., "Field trials and tribulations", supra note 30 , at p. 8 .

82 Art. 14 paras. 4 and 4a [German Federal Law of 1 July 1990 on the regulation of gene technology] Gesetz zur Regelung der Gentechnik vom 1. Juli 1990 (Gentechnikgesetz - GenTG) and §11 [Ordinance of 24 October 1990 on application documents and application procedures according to the German Federal Law an the regulation of gene technology] Verordnung vom 24. Oktober 1990 über Antrags- und Anmeldeunterlagen und über Genehmigungsund Anmeldeverfahren nach dem Gentechnikgesetz (GentechnikVerfahrensverordnung - GenTVfV).

83 Cf. $\S 11$ GenTVfV. The provision embodies into law the Commission decision of 4 November 1994 (94/730/EC) establishing simplified procedures concerning the deliberate release into the environment of GMP.

84 Cf. $\$ 11$ GenTVfV.

85 René Rhinow, Gerhard Schmid, Giovanni Biaggini, Felix Uhlmann, Öffentliches Wirtschaftsrecht, 2nd ed., (Basel: Helbling Lichtenhahn 2011), para. 40, at subpara. 35 .

86 Neue Zürcher Zeitung (NZZ), "Zerstörungsaktion in Gentech-Versuchsfeld" [destructive action on GMO trial field], 14 June 2008 available on the Internet at <www.nzz.ch/nachrichten/zuerich/zerstoerungsaktion_in_gentech-versuchsfeld_1.759006.html $>$ (last accessed on 12 July 2012).

87 Forschungsanstalt Agroscope Changins-Wädenswil (ACW), "Zwischenfall beim Feldexperiment mit gentechnisch verändertem Weizen in Pully" [incident during field release trial with GM-wheat in Pully], Press release of 25 June 2009, available on the Internet at <www.agroscope.admin.ch/aktuell/00198/00199/00344/04683/ index.html? lang=de\&msg-id=27717> (last accessed on 12 July 2012); Blick, "Gentech-Weizenfeld von Unbekannten sabotiert" [Trial field with GM-wheat sabotaged by unknown intruders], 7 July 2009, available on the Internet at <www.blick.ch/news/schweiz/gentech-weizenfeld-von-unbekannten-sabotiert-75259> (last accessed on 12 July 2012).

88 Cf. Gómez-Galera, Twyman, Sparrow et al., "Field trials and tribulations", supra note 30 , at pp. 6 et sqq., mentioning a variety of experimental field trials all over Europe which have been destroyed by activist. See also Economist Online, "Green Genes - The shameful destruction of a crop trial", 4 August 2008, available on the Internet at $<$ www.economist.com/node/11871937> (last accessed on 12 July 2012); lan Sample, "Anti-GM activists urged not to trash wheat field", The Guardian, 1 May 2012, available on the Internet at <http://www.guardian.co.uk/uk/2012/may/01/anti-gm-activistswheat-rothamsted $>$ (last accessed on 12 July 2012).

89 Thomas Bernauer, Theresa Tribaldos, Carolin Luginbühl and Micahel Winzeler, "Government regulation and public opposition create high additional costs for field trials with GM crops in Switzerland", in Transgenic Research (2011), DOI 10.1007/s11248-011-9486-x. (figures derived from his own research at Agroscope). 
the trial field. Efforts to implement such protected sites in Switzerland on a permanent basis now seem to be well under way. ${ }^{90}$

\section{Conclusions}

The authors of the present paper hope to facilitate research in the area of green gene technology. Under the existing legal framework, it will not be possible for this kind of research to be continued in Switzerland. Similar concerns have also started to be voiced in the European Union, where researchers face similar legal frameworks for experimental field trials, threats of destruction from activists and generally poor acceptance of transgenic crops by the public. ${ }^{91}$

The existing genetic engineering law aims for a very high level of protection. Legislators justify the

90 Staatssekretariat für Bildung und Forschung SBF (ed.), "Schweizer Roadmap für Forschungsinfrastrukturen - Schlussbericht", 30 March 2011, p. 47, available on the Internet on http://www.sbf.admin.ch/ $\mathrm{htm} /$ dokumentation/publikationen/forschung/11.03.30.NFO.RoadmapForschungsinfrastrukturen_d.pdf (last accessed on 12 July 2012). See for the concept also Hettich and Walther, "Schutz (vor) der Gentechnologie", supra note 23, at p. 86

91 Gómez-Galera, Twyman, Sparrow et al., "Field trials and tribulations", supra note 30 , at p. 11 . high level of protection on the grounds of the precautionary principle and the - as it is perceived - scientifically unclarified hazard situation. During almost 30 years of research in the area of biosafety of genetically modified plants, no scientific evidence has yet been found to suggest that genetically modified organisms pose a greater danger to the environment or for the safety of foodstuffs and fodder than do conventional organisms. The risks associated with field release trials of genetically modified organisms are now well known, limited in probability of occurrence and in extent of harm, and controllable by preventive measures. To abandon research and commercial use of green gene technology bears risk of its own. Given these circumstances, the legislators would be well advised to reconsider and adapt their risk assessment.

Against this background, at least the legal framework for research must be improved. The authors therefore propose the introduction of a framework or site approval in order to relieve researchers from procedural burdens. Furthermore, the authors believe that the research itself needs protection, which could be provided through the establishment of so-called "Protected Sites". The costs of these sites need to be borne by the government, at least in the case of fundamental research, which is being conducted mainly by the universities. 